\title{
Sustainability of Agriculture: The Neolithic Dilemma
}

\author{
Dave Flynn, Ph.D. \\ Professor, Hofstra University
}

\begin{abstract}
Water resources are being threatened by the use of fertilizers in farming in developing and developed countries. Significant changes are required of the world farming community to use more sustainable agricultural practices, otherwise the availability of clean water resources will reach catastrophically low levels worldwide. Suggestions are provided for reaching sustainable outcomes as the agriculture industry is necessary for feeding an ever-growing world population.
\end{abstract}

\section{INTRODUCTION}

As noted earlier (Flynn, 2018), the defining issue of the twenty-first century may well be the control and more generally, management of water resources. Water supplies are dwindling because of groundwater depletion, waste, and pollution, and demand is continuing to rise. Further, consumption of groundwater is increasing faster than it is naturally replenished, causing water tables to decline unremittingly (Sengupta \& Cai, 2019; Rodell et al., 2009). Currently, 338 million people are sometimes subject to severe water shortages and by 2025 this number is projected to increase to about 3 billion. Day Zero, when municipal water resources are unable to meet demand, plagues cities from Cape Town to Mexico City to Sao Paulo, Brazil. Nearly half of the human population is living with water scarcity, inhabiting places unable to fully meet drinking, cooking and sanitation needs (Subramanian, 2019). Efforts must be made to maintain sustainable water resources.

A sustainable economy must make investments in all forms of capital (human, social, and natural) to ensure that no form of capital is diminished in order to increase short-term output of marketable goods and service (Lant, 2004:22). "Sustainability of human activities (predominantly production and consumption) is a growing concern among businesses, customers, governments, international bodies and non-governmental organizations. These concerns are often linked to energy efficiency, reduction of environmentally harmful emissions, ecosystem preservation and other conservation efforts. They are becoming a part of a "triple bottom line" for business accounting: financial, social and environmental" (Hermanowicz, 2005). Water consumption by agriculture far outpaces other users. Water use in agriculture is at the core of any discussion of water and food security.

Furthermore, the use of fertilizers has led to the pollution of streams, rivers, and lakes. Patel and Parshina-Kotaas (2017) have reported on the devastating effects of agricultural run-off in streams and rivers has caused the polluting of Lake Erie through algae growth. Further, intense rains drive sewage and fertilizers into the waterways and coupled with warmer weather to heat waters create ideal conditions for algae blooms. These algae blooms caused the closing of New Jersey's largest inland waterway (see Figure \#1), Lake Hopatcong. This four-square mile lake was built as a resort. Attempts by four bordering townships are at an impasse to create storm water utilities as a mechanism for localities to charge fees to property owners according to how much water runoff they generate. Runoff not only increases flooding, it causes sewage, fertilizers and other pollutants to leach into lakes and oceans, nourishing bacteria (Barnard, 2019). These cyanobacteria blooms can cause ailments in people, but dogs and other animals 
are more susceptible as they often ingest them. Recently, dogs have died from exposure to these polluted waterways in Austin (Texas,) and Wilmington (N.C.) (Hauser, 2019).

\section{AGRICULTURE AND WATER CONSUMPTION}

Agriculture accounts for, on average, 70 percent of all water withdrawals globally, and an even higher share of "consumptive water use" due to the evapotranspiration requirements of crops. Worldwide, over 330 million hectares are equipped for irrigation. Irrigated agriculture represents 20 percent of the total cultivated land, but contributes 40 percent of the total food produced worldwide. At the same time, water in agriculture will continue to play a critical role in global food security. Population is expected to increase to over 10 billion by 2050, and whether urban or rural, this population will need food and fiber for its basic needs. Combined with the increased consumption of calories and more complex foods, which accompanies income growth in much of the developing world, it is estimated that agricultural production will need to expand $70 \%$ by 2050 . If this expansion is not to come at the expense of massive land conversions and the consequent impact on carbon emissions, agriculture will have to intensify. Given that irrigated agriculture is, on average, at least twice as productive per unit of land, provides an important buffer against increasing climate variability, and allows for more secure crop diversification, it is certain that irrigation will continue to play a key role in ensuring global food and nutrition security (WorldBank.org).

As suggested by Scott (2017), prior to The Neolithic Period, for roughly two hundred thousand years, modern humans lived as hunter-gatherers. Then, about twelve thousand years ago, came what is said to be our ascent to planetary dominance: the Neolithic revolution. This was our adoption of agricultural innovations that includes the domestication of animals including cows and pigs, and the transition from hunting gathering to planting and cultivating crops. The most important of these crops have been wheat, barley, rice and maize that remain the staples of humanity's diet. These cereal grains allowed population growth and the birth of cities and the rise of complex societies (Lanchester, 2017) (see Figure \#2). As a result of this societal shift to an agrarian society has, over time caused threats of water shortages to a quarter of humanity (see Figure \#3). Worldwide, seventeen countries are currently at risk of running out of water. Climate change is making the problem worse (Sengupta \& Cai, 2019).

In India, the water challenge is already grave and could get graver. By 2050, for instance, it is estimated that demand would go up to 1,180 million cubic metres, 1.65 times the current levels, a situation that would be made worse by fast dwindling fresh water resources (Vijayakumar, 2012). For example, the Yamuna River that flows through the ancient city of Delhi has helped sustain some of India's greatest empires. Hindu poets celebrated its life-giving properties. The Mughal dynasty built the Taj Mahal and other monuments along its banks. Today, the Yamuna is a foul sludge for much of its 855-mile run. In Delhi, it is black and nearly motionless, covered in many areas with a foam of industrial chemicals, floating plastic and human waste. Every 100 milliliters of the Yamuna in Delhi contain 22 million fecal coliform bacteria, up from 12,250 in 1988, scientists say. Anything over 500 is unsafe for bathing, India's government says. The comparable standard in Vermont is 235. Illnesses ranging from diarrhea to brain worms are reported along the river's edges. By the time the Yamuna exits Delhi, it is so defiled that scientists have declared the next 300 miles "eutrophic," or incapable of sustaining animal life (Pokharel \& Rana, 2017) (please Figure \#4).

A government report in 2015 found that 275 of 445 rivers in India are severely polluted, including the Ganges. An international nonprofit, WaterAid, says 70\% of India's surface water is contaminated. Diarrhea, often caused by drinking polluted water, is the fourth-leading cause of death in India, ahead of any cancer, and kills far more people than in China, which has a 
larger population. Greenpeace says that in 2015, the average Indian was subjected to more air pollution than the average Chinese for the first time, as China's "systematic efforts" to improve air have started working. A 2016 WHO report found that 10 out of the world's 20 most polluted cities were in India, based on residents' exposure to deadly small particulate matter (Pokharel \& Rana, 2017). South Asia has always been vulnerable to the vagaries of the monsoons that provide $70 \%$ of its water in a few months, feeding its rivers, recharging its groundwater and topping off the Himalayan peaks whose glacial meltwater sustains 1.65 billion people. But to even consider surviving the climate emergency underway, India needs more than megaprojects. It needs the collective power of abundant, small-scale, nature-based efforts to seize the seasonal bounty across the diverse landscape of South Asia. About half of 6,000 water bodies that once defined Chennai and its two neighboring districts are gone. Rampant development has destroyed the spaces that were natural sponges for monsoon rains (Subramanian, 2019).

Positive initiatives are more recently underway to help India, Zimbabwe and Mali with plant breeding techniques, including "speed breeding". Dr. Hickey of the University of Queensland (please see: https://qaafi.uq.edu.au/profile/108/lee-hickey) has been working on this technique that was inspired by NASA research into how to grow food on space stations by tightly controlling light and temperature to send pant in rapid growth where Hickey has shown that one can grow six generations pf wheat, barley, chickpeas and canola in a year, whereas traditional methods will only yield one or two (Shiekh, 2019: A13). Other solutions in India, specifically in the Alwar District of the northern state of Rajasthan, once-barren but now verdant valley that had been brought back to life by villagers who built small-scale earthen dams known as "johads." Thousands had been constructed across the district, strategically placed to capture fleeting monsoon rains in a cascade before the water "ran away," as a local told me. Aquifers - layers of water-permeable rock - were recharged, and wells that had been dry for a generation bubbled back into existence. Similar efforts are scattered across India. In the Kumbharwadi watershed of the western Indian state of Maharashtra, a program engaged locals in tree-planting and land-sculpting to capture water across the landscape. Groundwater levels rose, soil fertility improved, and agricultural income increased tenfold. In four years, the water tankers that citizens had depended upon in the dry season became obsolete (Subamanian, 2019).

\section{Hunters and Gatherers}

As reported by Lanchester (2017), anthropologist James Suzman, spent more than two decades studying the Bushmen of the Kalahari. About a hundred and fifty thousand years ago, fifty thousand years after the emergence of homo sapiens, the Bushman, or Khaosian moved to south Africa and still live there. They are divided into a norther group, who still have traditional control of their land and still have the opportunity to hunting and gathering of plant species. The southern Bushmen were deprived of their land and resettled into modern ways of living. The northern Bushmen have thrived and the southern Busmen have not. The hunting and gathering has continued to provide a balanced and sustainable way of life to this day.

For example, the indigenous tribes of Malaysia on Borneo were hunters and gatherers until their lands were acquired and turned into palm oil plantations. Also, one of the elders of the Kadazadadun and Murat communities, the indigenous tribes of Borneo in Miri (Malaysia) was photographed by the author in Miri in 2015, who was attending the celebration of the Kaamatan festival marking the end of rice harvesting. They represent one of the communities that have been "crowded out" as a result of cultivating palm oil (please see Figure \#5). 


\section{Neolithic Period and the Fertile Crescent}

Recent evidence suggests that in the Middle Stone Age (300,000 to 28,000 years ago), huntergatherers persisted and thrived at higher elevations of 11,000 feet in the Bale Mountains of southern Ethiopia at hundreds of thousand years ago. Evidence has also been found in caves on the Tibetan Plateau of human civilization 160,000 years ago (Zimmer, 2019). These ancient ancestors were believed to have subsided on giant mole-rats and fish from glacier-fed streams.

Then, the transition from the hunter-gatherer period, Early Stone Age, to the Neolithic, New (Late) Stone Age is evident in one of the first permanent villages in Syria and Palestine appear towards the end of the Natufian period (mid-late millennium B.C.) at on the upper Euphrates. Due to the location of the village on the permanent water source meant that year-round subsistence could be attained by combining fishing with seasonal use of wild plant and animal staples available in sufficient quantities to support a village with a sedentary population. As the village grew the development of small-scale irrigation would have yielded tangible subsistence benefits, as evidenced by charred grains of barley and einkorn found near the settlement (Miller, 1980). Upper Mesopotamia, which spans modern Iraq and part of Syria and Turkey, the Fertile Crescent, humans first domesticated animals and cultivated crops like wheat and barley. Five and a half thousand years ago, city-states in the region left behind the earliest evidence of writing and elaborate burial rites for kings. However, some of the same factors that allowed cities to grow may have ultimately caused them to disintegrate. Trella's studies in Upper Mesopotamia indicate that farming was intensified to provide more food to support growing populations. With limited transportation, cities depended on the fertility of nearby land. When populations were small, fields were left fallow biannually and used as grazing land for animals that fertilized the soil with their dung. Population growth changed this practice and potentially motivated the use of city wastes to fertilize fields. Analysis conducted on animal bones indicates that after several centuries of habitation, city dwellers no longer pastured their livestock in fallow fields, but instead moved them farther into the countryside, where their dung no longer benefited crops. All of these factors likely decreased agricultural sustainability (Bellows, 2010) (see Figure \#6).

The Neolithic Period or Late Stone Age, 7,000 to 10,000 years ago, pertains to a stage of culture following the Paleolithic and is characterized by the use of polished stone implements, development of permanent dwellings, cultural advances such as pottery making, domestication of animals and plants, the cultivation of grain and fruit trees, and weaving. The change from hunting/gathering to primitive farming appears so abrupt that this technological change is often characterized as the Neolithic Revolution. The discovery of smelting and the creation of bronze tools has given the name Bronze Age to the Late Neolithic period (Hortticulture). However, arguably, health is one variable that is a good indicator of quality of life. Human bones reveal that many of the people living in cities during their heydays had impoverished diets, suffered from more disease and infant mortality, and lived shorter lives than their nomadic counterparts (Bellows, 2010).

\section{Biotech in Agriculture}

Biotech crops, genetically modified organisms (GMOs) have been steadily growing throughout the developed and developing world (see Figure \#7). While the biotech crops are created to be resistant to various forms of blight, some biotech products may be less beneficial to the ecosystem. Monsanto, for example, has involved in litigation in the United States involving one of its weed-killing fertilizers, Roundup. The active ingredient is glyphosate may cause nonHodgkin's lymphoma as claimed by farmers, their families, and others (Hakim, 2017). European Union officials are considering blocking the use of glyphosate in its 28 nations. In the defense of bio-engineering Hugh Grant of Monsanto and James Collins of DuPont have 
considered the use of Crispr, the gene editing technique to increase the use of bioengineering for the future of agriculture after more than two decades of genetically modified organisms' usage in agriculture (Wall Street Journal, 2017). It's hard to imagine maintaining the current food system without Iowa. Yet that state - symbolic of both the unparalleled richness of our continent's agricultural potential and the mess we've made of it - has undergone a transformation almost as profound as the land on which cities have been built. A state that was once 85 percent prairie is now 85 percent cultivated, most of that in row crops of corn and soybeans. And that isn't sustainable, no matter how you define that divisive word (Bittman, 2014). Most of the corn are used in ethanol production, a unsustainable additive in gasoline, and soybeans, both of which are used for animal feed and little for direct human consumption. As Bittman (2014) argues it's easy enough to argue that one of the most productive agricultural regions in the world could be better used than to cover it with just two crops the two crops that contribute most to the sad state of our dietary affairs, and that are used primarily for animal food, junk food and thermodynamically questionable biofuels. Further, many Iowa farmers have believed that if they weren't 100 percent "in" corn, they weren't doing a good job. Because of the pressure to plant, many of them have expanded their cultivated areas beyond areas that were viable, creating erosion and runoff problems. Iowa is among the major contributors to the Gulf of Mexico's "dead zone," a direct result of fertilizer runoff into the Mississippi water system, and half of Iowa's topsoil has been lost.

Another herbicide, dicamba, has been found to damage 3.6 million acres of soybean, crops, or about 4 percent of all soybeans planted in the United States in 2017. Dicamba has been used beginning in 2017, on genetically modifies soybeans and cotton crops that are grown from seeds created (GMO) to be tolerant of weed killers. The problem is that the herbicide can drift off the fields where it is being applied, landing on nearby farms where conventional soybean seeds have been planted. An estimated 22 million acres of soybean crops were planted with GMO seeds out fan estimated 89.5 million acres of soybeans planted nationwide (Lipton, 2017). Further, the algae outbreak in Lake Erie was most recently caused by phosphorous run-off from the Maumee and Sandusky rivers. Blue-green algae feeds on phosphorous which has sickened people and animals and caused damage to fishing and tourist industry (Maher, 2018: A3).

However, as argued by Lynas (2018) the problem is not only that almost all of the alarms about GMOs were false. It's that the anti-GMO campaign has deprived much of the world of a crucial, life-improving technology-and has shown the readiness of many environmentalists to ignore science when it contradicts their prejudices. Contrary to our initial fears, the overall impact of genetically modified crops has been to dramatically reduce the amount and toxicity of pesticides sprayed by farmers. Crops such as Bt corn, so called because it incorporates proteins toxic to insects from the bacterium Bacillus thuringiensis, have enabled farmers to rely less on sprayed insecticides. A meta-analysis, combining the results of nearly 150 peer-reviewed studies, was published in 2014 in the highly regarded journal PLOS One. It concluded that GMO crops used $37 \%$ less chemical pesticide (that is, both insecticide and herbicide) than conventional versions of the same crops, thanks largely to the new crops' internal biological protection against insects.

Pesticide reductions have been especially notable in developing countries. In Bangladesh, for instance, small holder farmers have benefited from Bt varieties of eggplant. In the past, they often sprayed their crop with toxic chemicals as many as 100 times in a season to fight off pests. The GMO eggplant has enabled them to dramatically reduce insecticide spraying, in some places almost to zero. Furthermore, the GMO seeds reproduce perfectly well. Those Bangladeshi farmers save and share their new Bt eggplant seeds, helping their neighbors and 
extended families also to reduce pesticide spraying. Many crops now in development in African countries, such as drought-tolerant corn and disease-resistant banana and cassava, will be sold royalty-free by local seed companies in an effort to improve the livelihoods of subsistence farmers and reduce poverty (Lynas, 2018).

\section{Fertilizers Pollute Waterways}

As reported by Tabuchi et al. (2018: A13), flooding throughout the United States is likely to worsen because of climate change, the federal government warned last year. Heavy rainfall is increasing in intensity and frequency. At the same time, rising sea levels combined with more frequent and extensive flooding from coastal storms like hurricanes may increase the risk to chemical facilities near waterways. The New York Times analysis looked at sites listed in the federal Toxic Release Inventory, which covers more than 21,600 facilities across the country that handle large amounts of toxic chemicals harmful to health or the environment.

Of those sites, more than 1,400 were in locations the Federal Emergency Management Agency (FEMA) considers to have a high risk of flooding. An additional 1,100 sites were in areas of moderate risk. Other industrial complexes lie just outside these defined flood-risk zones, obscuring their vulnerability as flood patterns shift and expand. The presence of chemical sites in areas vulnerable to flooding is a holdover from an age where the advantages to industry of proximity to rivers and oceans - for transportation and trade, or for a ready supply of cooling water - seemingly outweighed the risks.

"Waterfronts are changing as a result of sea level rise," said Jeanne Herb, an environmental policy expert at Rutgers University who has researched hazards posed by climate-related flooding to industries in New Jersey. "More often than not, these are facilities are on the water for a reason," she said. "So how do we make sure that there are protections in place? That's the big question." Federal law does not explicitly require sites in floodplains that handle toxic chemicals to take extra precautions against flooding. Nor do most states or local governments have such requirements (Tabuchi et al., 2018: A13). The recent flooding as a result of Hurricane Harvey caused a release of lye into the waters in Barrytown, Texas. This is the case along the Gulf Coast because the country's oil, gas and petrochemicals industries are concentrated there. At least 46 facilities reported an estimated 4.6 million pounds of airborne emissions beyond state limits between Aug. 23 and Aug. 30, 2017, the week spanning Harvey's approach and landfall in Texas. The Chevron Phillips plant also reported one of the largest Harvey-related emissions of chemicals into the air.

When Tropical Storm Debby brought torrential rain to north and central Florida in mid-2012, it triggered a release of phosphoric acid from a chemical plant in White Springs that produces phosphates, which are used to make fertilizer. Flooding knocked out the power supply to its pumping system, causing water mixed with chemicals to spill into a storm-retention pond, which eventually also overflowed into a creek that feeds the Suwannee River. Released in large quantities into the environment, phosphates and phosphoric acid can cause uncontrolled algae and duckweed growth, causing oxygen levels in lakes and rivers to drop precipitously (Tabuchi et al., 2018).

In a study published in the Proceedings of the National Academy of Sciences (Plumer \& Popovich, 2018: A10), researchers found that, since 1982, between 3 and 10 percent of the country's water systems have been in violation of federal Safe Drinking Water Act health standards each year. In 2015 alone, as many as 21 million Americans may have been exposed to unsafe drinking water. The problem is particularly severe in low-income rural areas, the study found. And the researchers identified several places, including Oklahoma and West 
Texas, that have repeatedly fallen short in complying with water safety rules issued by the Environmental Protection Agency over the past decade. "These are often smaller communities flying under the radar," said Maura Allaire, an assistant professor of urban planning at the University of California, Irvine, and a lead author of the study. "They're struggling to maintain their aging infrastructure, and they're struggling to keep up with the latest water treatment techniques" (Plumer \& Popovich, 2018: A10). A century-old water tunnel that carries irrigation water across more than 100 miles, from Wyoming to Nebraska, collapsed. As a result, more than 100,000 acres across these two states are without water so crops are dying (Smith, 2019).

In reporting on beekeepers in cites, Schuetze and Karasz (2019: A6) identify the critical role of honeybees to crop success through pollination. However, around the world, bee colony collapse disorder has significantly reduced honeybee populations over the past two decades, a crisis that has been arguably caused by pesticides, herbicides, monoculture farming and a warming climate that favors parasites like mites. Many wild creatures that pollinate crops and other plants have also declined, including wild bee species, moths, butterflies, wasps, beetles, bats and birds. They may be threatened by the same forces as honeybees, and their living space is reduced every year by human expansion. Honeybees provide a valuable service to humans, but despite what many people believe, studies have not found that raising them contributes to biodiversity. In fact, in an area like Berlin that has too many bees, they can harm biodiversity. They may deplete the nectar that wild insects depend on, and diseases spread more readily among managed species than wild ones. Instead, city dwellers should pressure officials to keep parks wild during the full life cycle of insects, not just when wildflowers are in their prime, and to avoid using pesticides.

\section{FARMING SOLUTIONS FOR SUSTAINABLE DEVELOPMENT}

In less than 100 years, palm oil has moved from being a relatively minor subsistence crop in West and Central Africa to one of the world's major agricultural commodities. While oil palm in Africa has been cultivated for centuries by deliberate plantings and selective clearing, it has recently expanded dramatically in Southeast Asia, and increasingly in Africa and Latin America (Sayer, et al. (2012: 114). Palm oil production in Indonesia and Malaysia represents $33 \%$ of the world's total production (Muna, 2016). Demand for palm oil continues to increase from India, Europe, China and the United States. Uses for palm oil is quite broad especially as fillers in many food products. Palm oil and its derivatives are part of thousands of products across the globe today. One can find it in biodiesel, soap, doughnuts as well as soap, to mention only a few. Since 1990, palm oil consumption has quintupled worldwide. The demand in Asia, where palm oil is used in cooking oil, accounts for a $\$ 44$ billion industry. Indonesia is the world's largest producer of palm oil, with a forecasted annual growth in production of $10 \%$. Early 2013, exports from Indonesia hit a five-year high (UDP.org).

There do exist many obstacles to the sustainability of palm oil production especially if producers do not abide by the directives of the Roundtable on Sustainable Palm Oil (RSPO) certification, as one example. At present, only about $10 \%$ of palm oil producers are RSPO certified. As a result, rivers have become polluted and air carries noxious particulates that result in environmental degradation and critically premature deaths. For example, smoke related deaths from burning to allow for agriculture has resulted in 100,300 premature deaths in Southeast Asia from July through October 2015 (Schonhardt, 2016). Further, in the fall of 2015, Indonesia released more carbon per day than the European Union (Fountain, 2017).

In Iowa, A long-term research project at Iowa State University is marking a major milestone by publishing 10 years of data on the various benefits provided by planting strips of prairie 
among corn and soybean fields. STRIPS, which stands for Science-based Trials of Rowcrops Integrated with Prairie Strips, is a group of scientists researching the benefits that may be derived from integrating prairie into crop production systems. The researchers, led by Lisa Schulte Moore, a professor of natural resource ecology and management, gathered data on dozens of ecosystem performance metrics. The results show prairie strips offer a range of environmental benefits at a lower cost than many other conservation techniques, Schulte Moore said. Social survey results also presented in the paper portray Iowans' support for agricultural policies that produce outcomes such as those provided by prairie strips. The prairie strips reduce soil and nutrient loss from steep ground, provide habitat for wildlife and improve water infiltration. According to the study published by PNAS, converting as little as 10 percent of the cropped area to prairie conservation strips reduced soil loss by 95 percent, phosphorus losses in surface runoff by 77 percent, nitrate concentrations in groundwater by 72 percent and total nitrogen losses in surface runoff by 70 percent, compared with all-crop watersheds. Pollinator and bird abundance more than doubled (Iowa State University, 2017).

\section{Forest Preservation and Soil Management}

All peatlands, where palm oil production thrives, consists of slowly decomposing vegetation in swamp forests, that has been accumulating for more than 10,000 years. Peat covers only about 3 percent of the Earth's land surface, but because it stores carbon over a long time, it contains as much carbon as all of the world's plants and trees, and almost as much as the atmosphere. Most peatlands are in northern regions, including Alaska, Canada and Russia. But tropical peatlands, especially are highly vulnerable to land-use changes and climate warming, both of which can lead to peat drying out and decomposing quickly, which would release the carbon back into the atmosphere. Recently, scientists have mapped what is the largest peatland in the tropics, an area larger than New York State in the Congo Basin in Central Africa (Fountain, 2017). If this land is not preserved, environmental damage may be daunting. According to Emma J. Stokes, who directs the Central Africa program for the Wildlife Conservation Society, said that protecting the peatlands was crucial, as the swamp forests are home to many animals, including some of the highest densities of lowland gorillas anywhere (Fountain, 2017).

As suggested earlier, the lack of oversight has led to the clearing of forests across Southeast Asia for oil palm production. However, fortunately, in Sarawak, Malaysia on the island of Borneo, the government has succeeded in preserving $68 \%$ of the original forest according to Natural Resources and Environment Minister Wan Junaidi (Bahari, 2016).

According to Dr. Lulie Melling, the Director of the Tropical Peat Research Laboratory Unit (TPRL), "one of the most appropriate methods to resolve the problem of peat fires is by compacting the soil using excavators...consolidating the soil will increase the moisture holding capacity of the soil...via a capillary rise of the soil...to prevent the occurrence of fire." (Bernama, 2016: A1). Sarawak uses such a process virtually eliminating the chance of fires, whereas in Kalimantan Province of adjacent Indonesia is among the regions facing the most serious problems due to pet fires, with the Air Pollution Index (API) reposted in some areas to be more than 2000 in March of 2016 where an API of 3000 is considered dangerous.

Soil management was carried out by draining the peat, compacting it, and then controlling the water levels to ensure good soil conditions and moisture levels resulting in better yields of palm oil. Indonesia has more than 4,000,000 hectares of abandoned peat land creating the opportunity for fires without proper soil management (Bernama, 2016).

Researchers at North Carolina State University have developed portable technology that allows farmers to identify plant diseases in the field. The handheld device, which is plugged into a 
smartphone, works by sampling the airborne volatile organic compounds (VOCs) that plants release through their leaves. In proof-of-concept testing, the researchers demonstrated the device's ability to detect and classify 10 plant VOCs down to the parts-per-million level. They were able to detect the late blight pathogen that caused the Irish famine two days after tomato plants were inoculated with the pathogen. Researchers could also distinguish tomato late blight from two other important fungal pathogens that produce similar symptoms on tomato leaves. In addition, the researchers showed they could detect the pathogen Phytophthora infestans in tomato leaves with greater than 95\% accuracy (Shipman, 2019).

Further consideration of indigenous species being crowded out of their habitat must include the orangutans, especially on Borneo. The Borneo orangutans was declared critically endangered in 2016, after research showed its population had declined by more than 80 percent over the past 75 years, mainly due to habitat destruction (Emont, 2017a). Further research has shown that the off- spring of orangutans breast feed now for up to 9 years, the most of any primate. The study found evidence that during periods when fruit and other food became scarce, young orangutans would supplement their diet with breast milk according to Christine Austin an author of this study and a researcher in the department of Environmental Medicine and Public Health at the Icahn School of Medicine at Mt. Sinai (NPR, 2017).

Recently, there has been discovered that there is a seventh great ape species: the Tapanuli orangutan from the upland forest on the Indonesian island of Sumatra. Unfortunately, the Tapanuli orangutan may be the most endangered of all surviving apes, with only about 800 left. The Tapanuli orangutan population became isolated from other Sumatran orangutan populations sometime in the last 10,000 to 20,000 years (Cochrane, 2017). This species is being crowded out of their habitat by the exploitation of forests as experienced by other orangutans in Sumatra and Borneo. More recently, to estimate changes in the size of Borneo's orangutan population over time, researchers representing 38 international institutions compiled field surveys conducted between 1999 and 2015. They extrapolated the overall size of the island's population from the number of orangutan nests found throughout the species' range in Borneo. The team observed 36,555 nests and estimated a loss of 148,500 orangutans during that period. The data also suggested that only 38 of the 64 identified groups of orangutans now include more than 100 individuals, which the researchers say is the lower limit to be considered a viable grouping. That would leave the surviving number at around 148,000 , according to the report. However, the World Wildlife Fund estimates that the remaining population of Borneo orangutans is much smaller, at around 105,000 . The causes include illegal logging operations, slash-and-burn land clearing, hunting and other direct conflicts with humans (Cochrane, 2018: D2). Beech (2019) tells the story of a orangutan who was shot and blinded as her baby was stolen from her by a boy in the local village. But the orangutans stole fruit from their gardens and trees so they felt justified. The orangutans lose acres each day to palm oil production. Sustainability includes all local populations that must share diminishing natural resources.

\section{Sustainability of Palm Oil Production in Malaysia and Indonesia}

Palm oil could help achieve high land use efficiency as its about 10 times more than other oilseed crops (Palm Oil Facts \& Figures Factsheet, 2012). The energy yield ratio of palm biodiesel is 3.53, which is more than double that of rapeseed biodiesel (Yee et al., 2009), and also performs better than other competing oils, including soybean (Tan et al., 2009), coconut and jatropha (Pleanjai, 2009). In terms of greenhouse gas (GHG) emissions, a carbon saving benefit of $38 \%$ is achievable with the replacement of conventional diesel fuel with palm biodiesel (Yee et al., 2009). Oil palm plantation also allows agro-forestry and livestock crop integration (Tan et al., 2009), which could increase the intensification of land use in Malaysia. 
The plantation area of oil palm in Malaysia has increased by $150 \%$ over the past 30 years (Fairhurst \& Mutext, 1999). The fragmentation of forest associated with this man-made monoculture has adversely affected the forest ecological functions and threatens the already endangered species such as orangutans, elephants, tigers, and rhinos (Ardiansyah, 2006). Land clearing activities for palm oil plantations have been identified as the root cause for forest and peatland fires (Datamonitor, 2010) in Southeast Asia each year, which affect the health of millions of people in the region suffered from pneumonia and other respiratory diseases (Food and Agriculture Organisation of the United Nations, 2006).

As mentioned earlier, the majority of the world's palm oil production is in Indonesia and Malaysia. As suggested by Lim et al. (2015), the success of sustainability efforts in Malaysia has met with limited success where the economic benefits of palm oil production have not fulfilled the commitment to many of the non-industrial stakeholders. The existing palm oil production is economic focused rather than ecologically focused causing the disappearance of animal species and cultural values of those in the forest areas. The palm oil industry started with economic imperatives, rather than considering ecological issues by converting forests for palm oil production damaging natural environments and thus disempowering the local indigenous community (Lim et al., 2015: 14).

According to Sayer et al. (2012:117-118) the first of the ecosystem principles adopted by the Convention on Biological Diversity is that conservation is a matter of societal choice (Sayer and Maginnis, 2005). As such, many tropical countries with large populations of poor rural dwellers will opt for oil palm rather than natural forest. While there is still a long way to go, and many improvements to be made, the rate at which goals of equity and sustainability will be achieved is ultimately a function of consumer behavior and, as the Convention on Biological Diversity has acknowledged, a societal choice (Sayer et al., 2012: 118).

\section{CONCLUSION}

While it is a quaint thought to attempt a large scale return to a hunter and gatherer society, it is feasible to preserve those cultures that still maintain such a way of life. Further, reducing and limiting the exploitation of these lands for farming of arguably, unsustainable crops and foodstuffs, especially meat, as discussed in a recent United Nations study (Flavelle, 2019). Other solutions include the use of tiny beads of engineered resins that can absorb phosphorous. Other ideas include the use of substances inserted into tiles under the soil on farms to remove phosphorous before it reaches the rivers (Maher, 2018). Reluctantly, we may have to accept the use of GMO pest resistant crops to minimize the use of fertilizers.

Ultimately, a balance needs to be achieved, albeit incrementally, balancing development and environmental needs, a concise definition of sustainable development. This can be achieved with cooperation of the various constituencies of indigenous people, government policy makers, environmental agencies, and consumers. Therein, a sustainable solution may exist for fulfilling the increasing demands of food production and consumption to a ever increasing world population. 
Figure \# 1: Lake Hopatcong with the green blooms of cyanobacteria (Barnard, 2019).

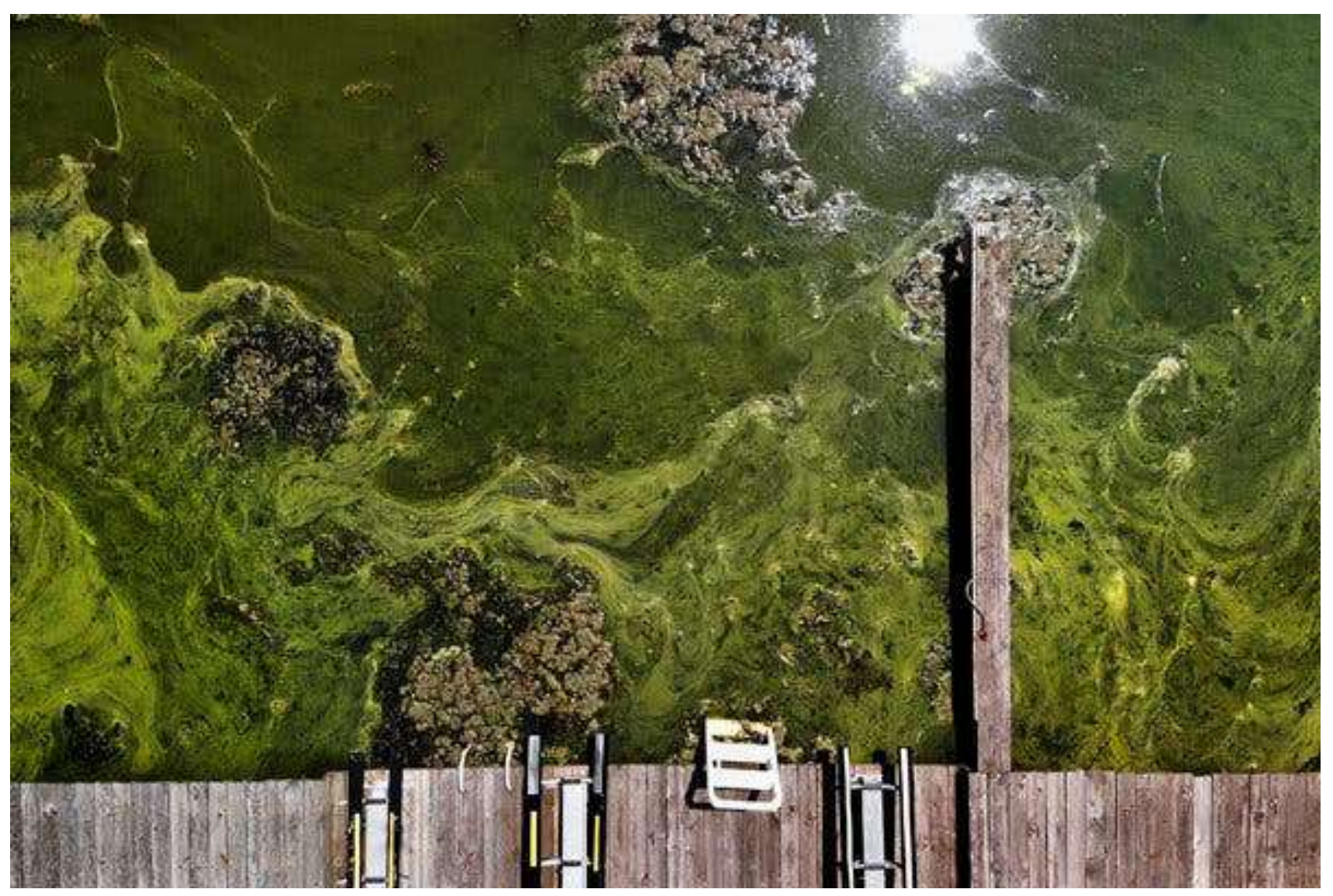




\section{Figure \#2}
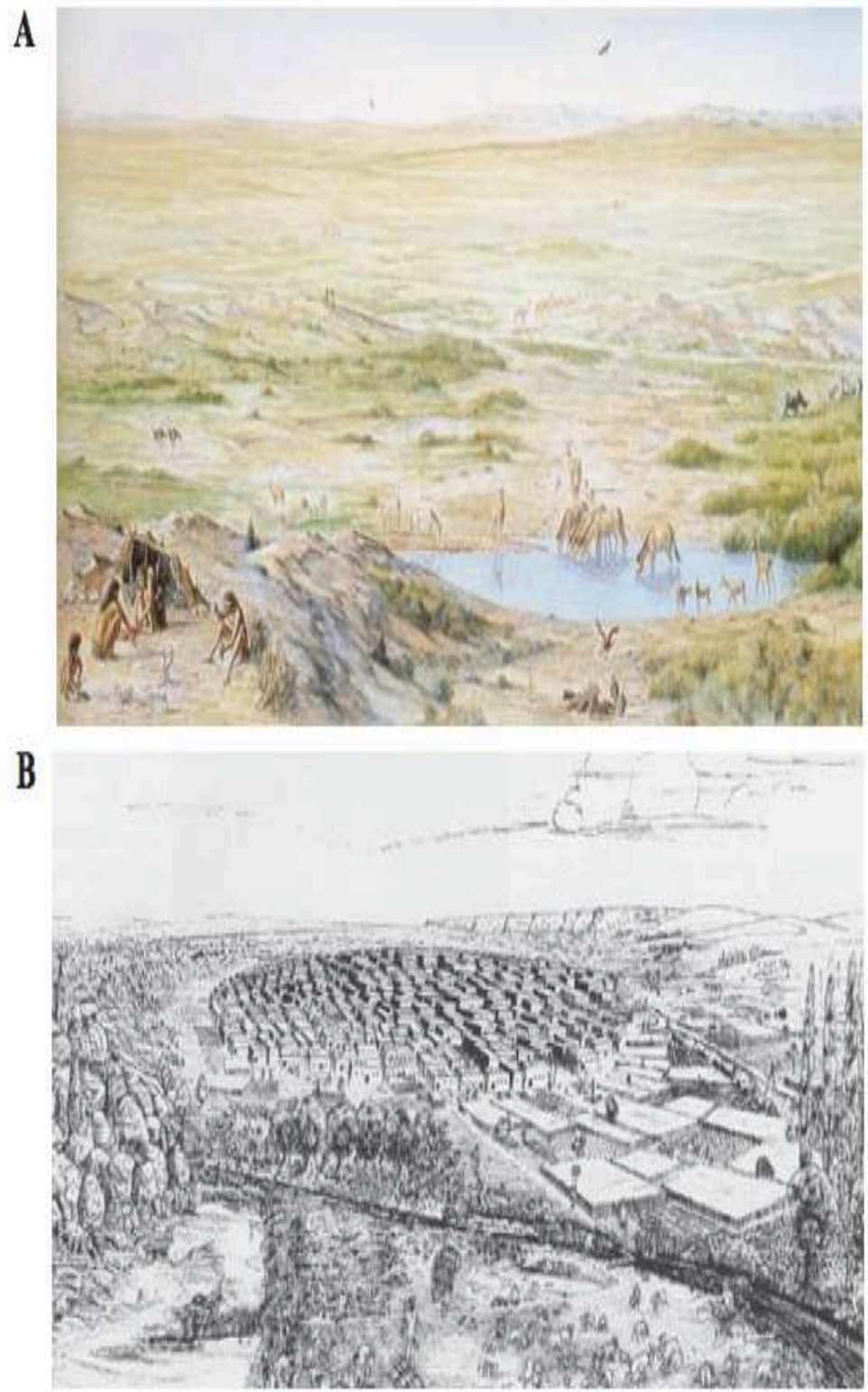

Reconstruction of Paleolithic (2,000,000 to 10,000 BCE) landscape (A) and Neolithic (10,000 to 3,000 BCE) village at Abu Hureyra (B) in Syria. 


\section{Figure \#3}

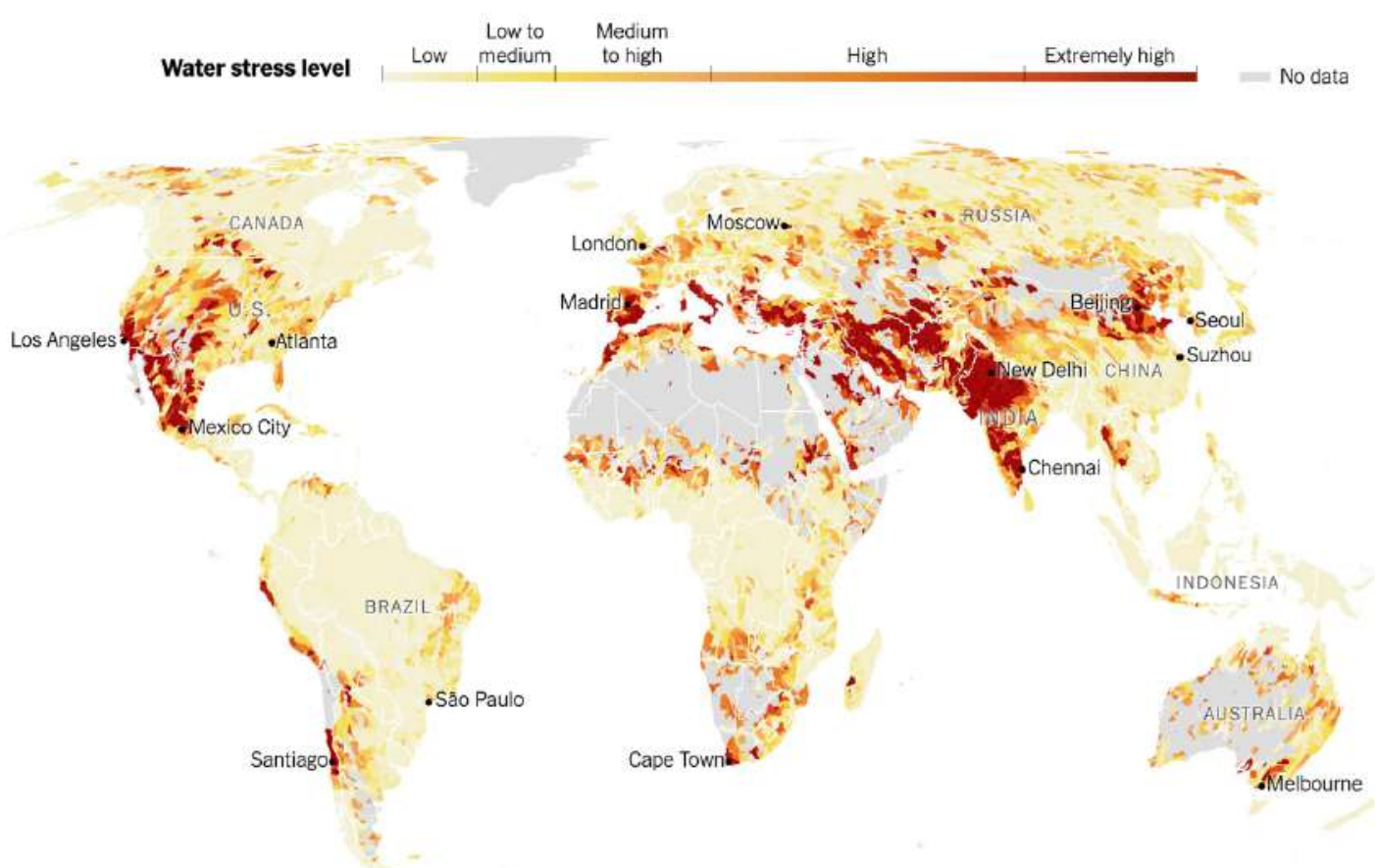

Figure \#4

\section{River of Shame}

The Yamuna River once helped sustain some of India's greatest empires. Now it is a foul sludge for much of its 855 -mile run, with soaring levels of dangerous bacteria.

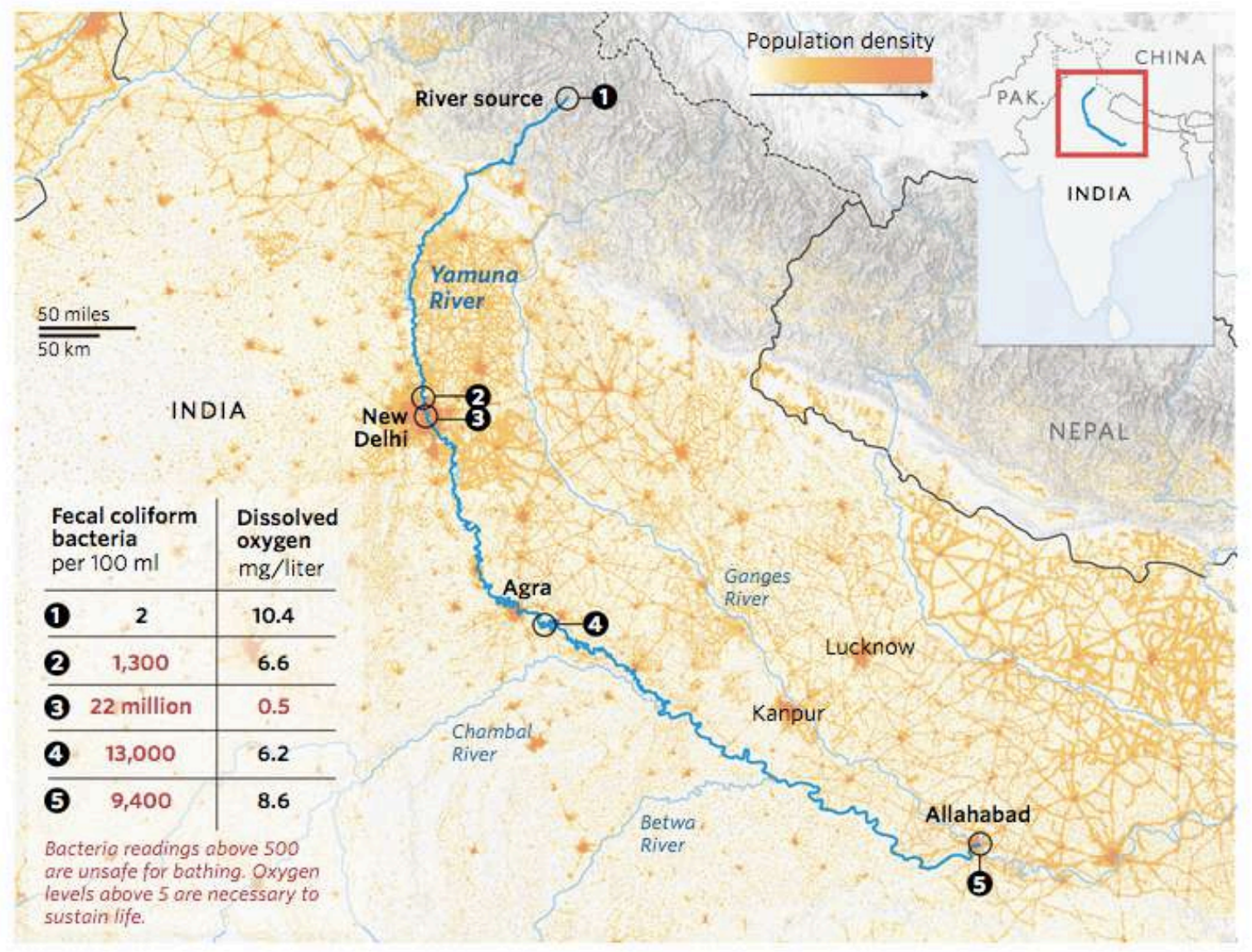

Sources: Central Pollution Control Board (fecal coliform, oxygen); Oak Ridge National Laboratory's LandScan dataset (population density) 


\section{Figure \#5}

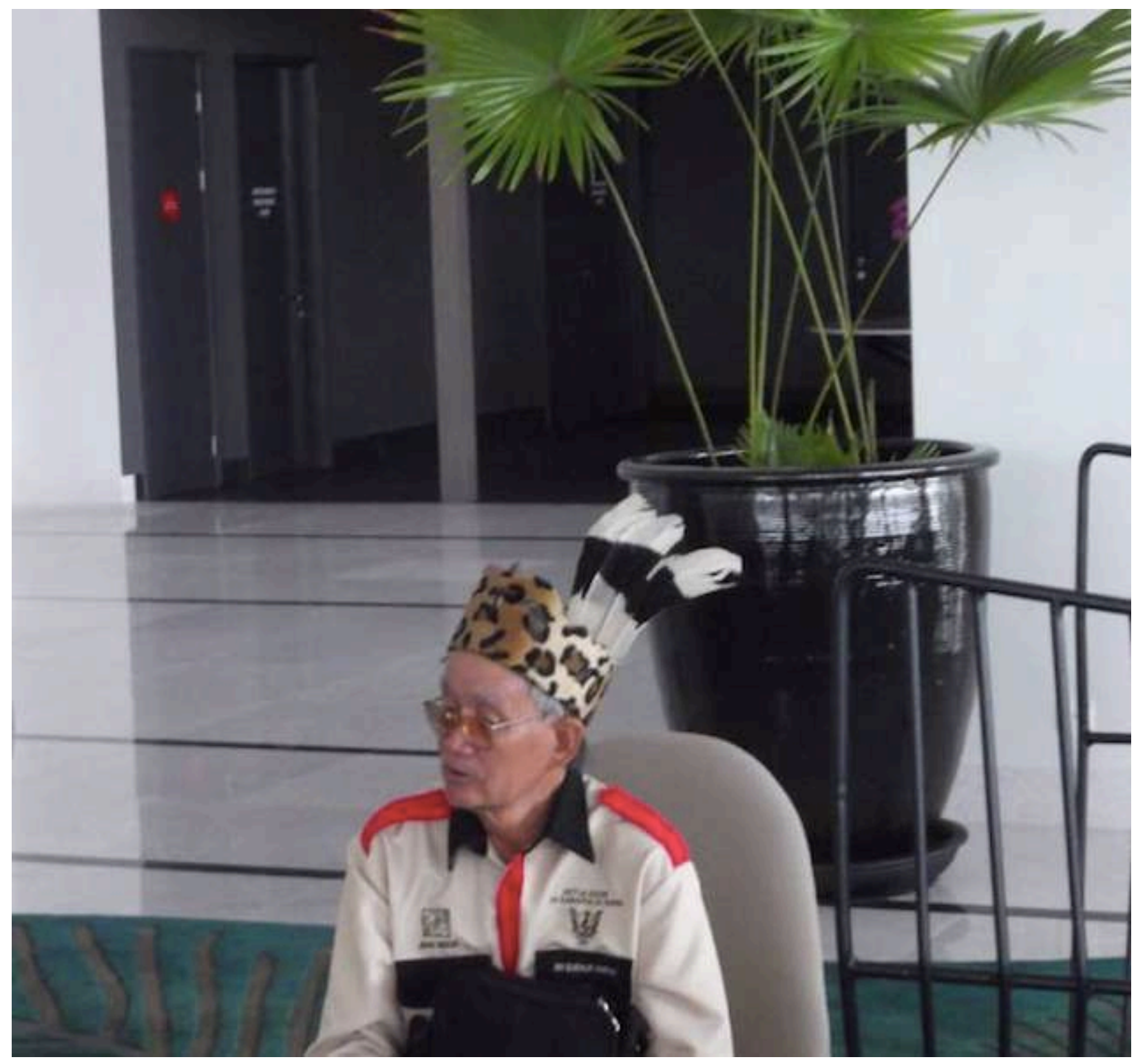




\section{Figure \#6}

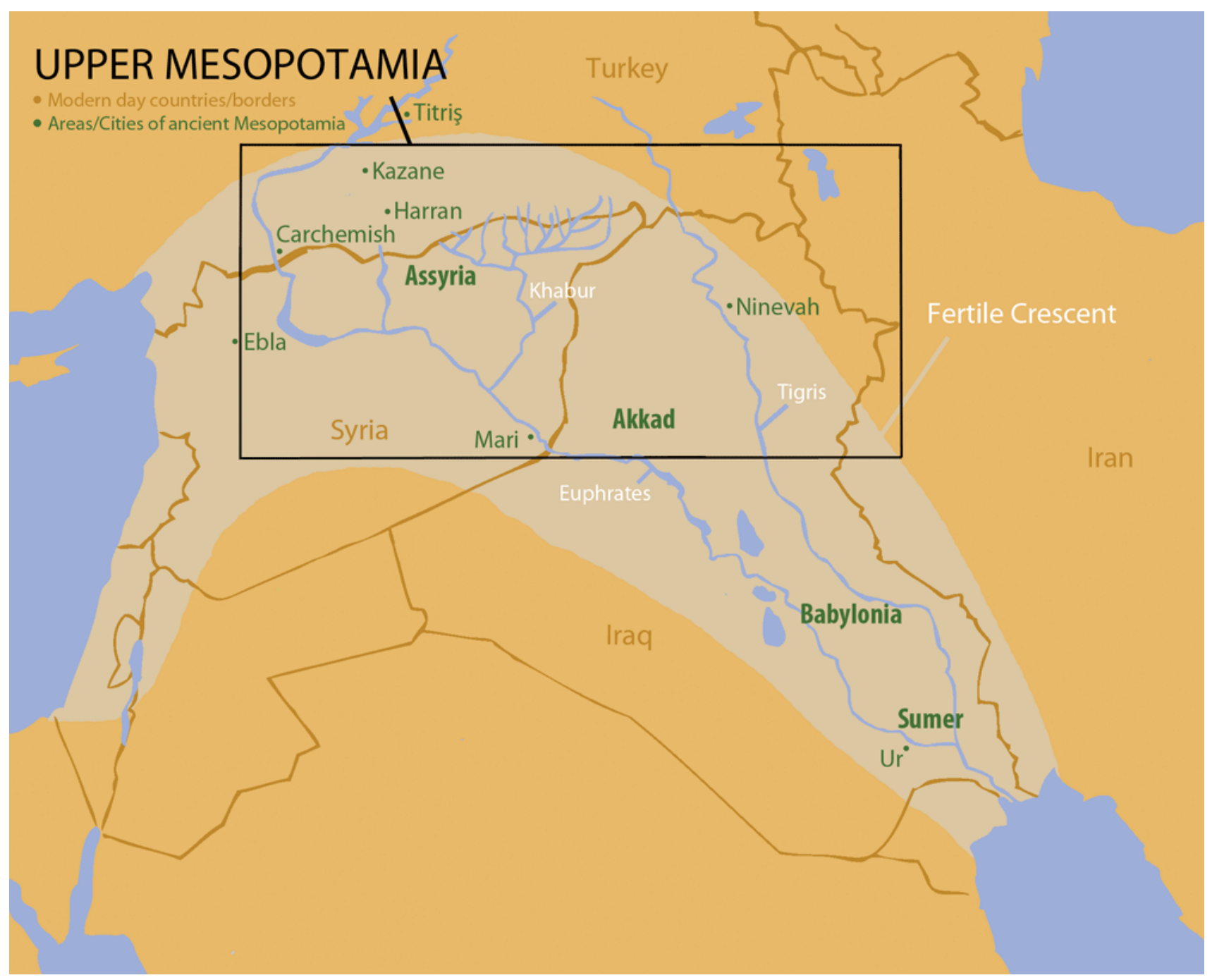

The study of early civilizations brings archaeologists to the Near East, where the ruins of several-thousand-year-old city-states show evidence of the first agriculture, irrigation, animal domestication, writing and organized religion. Modern states-Turkey, Syria and Iraq-now exist in territory that was once Assyria, Babylonia and Sumer.

Source: https://uvamagazine.org/articles/the trouble with civilization 


\section{Figure \#7}

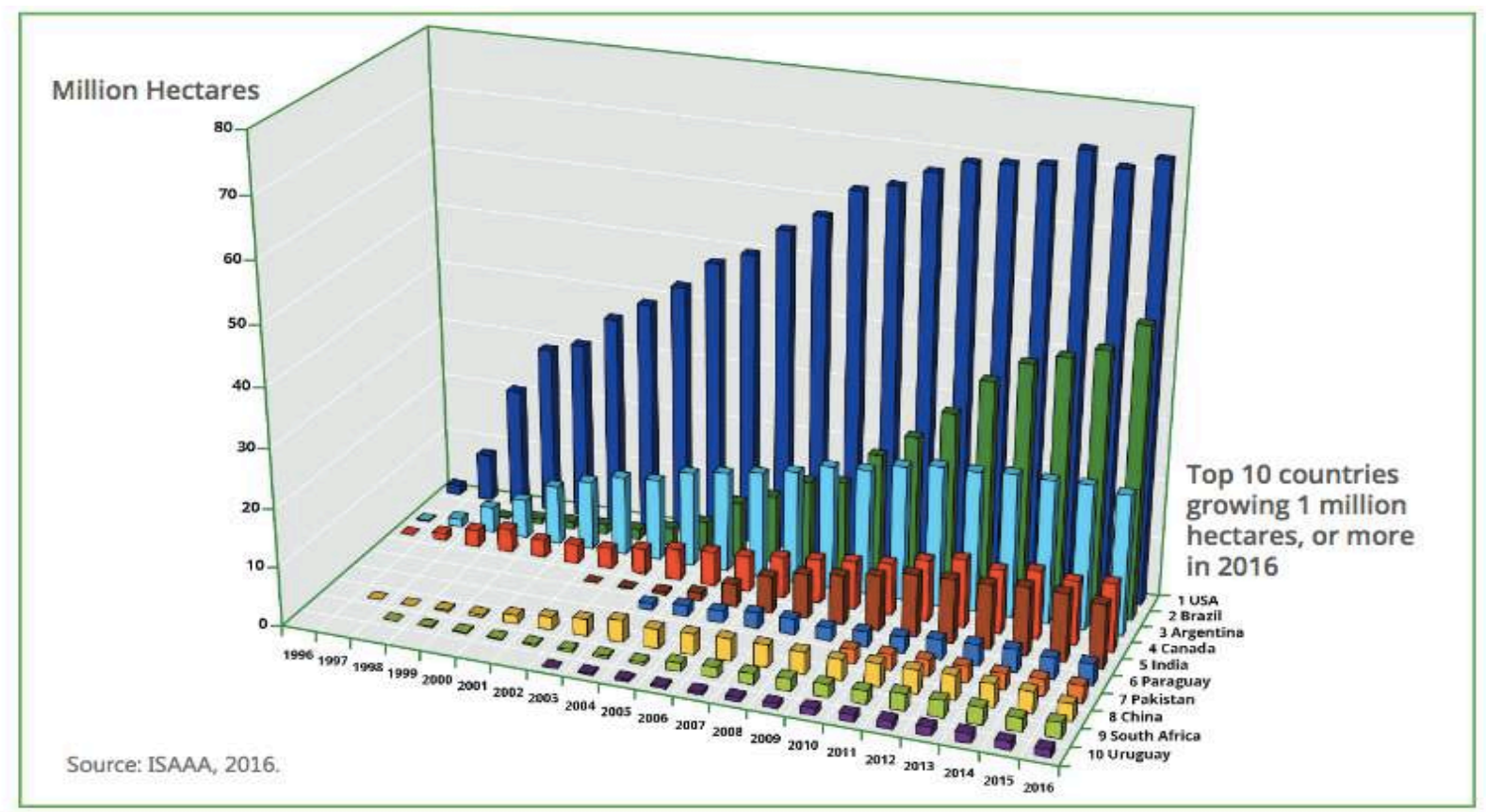

\section{BIBLIOGRAPHY}

Ardiansyah, F. (2006). "Sustainable Oil Palm Development in Indonesia - Challenges and Opportunities." WWF (ed.), International Palm Oli Conference.

Bahari, S. (2016). “Government takes forest preservation seriously, says Wan Junaidi.” Borneo Post, May 23, A1.

Barnard, A. (2019). “Algae Vloom Fouls New Jersey’s Largest Lake and Ruins Summer.” New York Times, August 5, A17.

Beech, H. (2019). “Of Palm Oil, Forest and Orangutans.” New York Times, July 16, A2.

Bellows, S. (2010) "The Trouble with Civilization: Ancient cities reveal the vulnerabilities of modern societies." Fall: https://uvamagazine.org/articles/the trouble with civilization

Bernama (2016). "Prevent Peat Fires Via Soil Management'. Borneo Post, 23 May, A1.

Bittman, M. (2014). "A Sustainable Solution for the Corn Belt." New York Times, 18 November.

https://www.nytimes.com/2014/11/19/opinion/a-sustainable-solution-for-the-corn-belt.html

Cochrane, J. (2018). "Orangutan On Island of Borneo Succumb to Bullets and Bull Dozers." New York Times, 20 February, D2.

Cochrane, J. (2017). "New Orangutan Species May be the Most Endangered." New York Times, 3 November, A8. Datamonitor ((2010) "Palm Oil Case Study: How Consumer Activism Led the Push For Sustainable Sourcing."

Emont, J. (2017a). "A Refuge for Orangutans Presents a Quandary for Environmentalists." New York Times, 26 April, A4.

Emont, J. (2017b). “Python Swallows an Indonesian Villager Whole.” New York Times, 30 March, A10.

Fairhurst, T.H. \& Mutert, E. (1999). "Introduction to Palm Oil Production." Better Crops International, 3-6.

Feintrenie, L., Chong, W.K., \& Levang, P. (2010). “Why do farmers prefer oil palm? lessons learnt from Bungo District, Indonesia." Small-Scale Forestry, 9, 379-396.

Flavelle, C. (2019). "The Food Supply Is At Risk, U.N. Experts Say." New York Times, August 8, A1 \& A7.

Flynn, D. (2018). "Sustainability and Agriculture." Archives of Business Research, 6, 8, 148-164.

Flynn, D. (2014). "Sustainable Development and Water Resource Scarcity." Archives of Business Research, 2, 5, 1228. 
Hakim, D. (2017). “Monsanto’s Roundup Faces European Politics and U.S. Lawsuits.” New York Times, October 5, B3.

Hauser, C. (2019). “Poisonous Algae Blooms Are Killing Dogs.” New York Times, August 13, A10.

Hermanowicz, S.W. (2005). "Entropy and Energy: Toward a Definition of Physical Sustainability.” Working Paper, (http://repositories.cdlib.org/wrca/wp/swr v2).

Hickey, L. https://qaafi.uq.edu.au/profile/108/lee-hickey

Horticulture and \& Landscape Agriculture: Purdue University (Hort). "Neolithic Revolution and the Discovery of Agriculture." https://hort.purdue.edu/newcrop/Hort 306/text/lec03.pdf

International Service for the Acquisition of Agri-biotech Applications (ISAA) (2016). "Global Status of Commercialized Biotech/GMO Crops: 2016."

https://www.isaaa.org/resources/publications/briefs/52/download/isaaa-brief-52-2016.pdf

Iowa State University (2017). "Iowa State University project: Prairie Strips yield big environmental benefits."

October 3. (https://www.news.iastate.edu/news/2017/10/03/strips10years)

Lanchester, J. (2017). “How Civilization Started.” New Yorker, 18 September: 22-26.

Lant, C. (2004). “Water Resources Sustainability: An Ecological Economics Perspective.” Water Resources Update, 127: 20-30.

Latham, K.J. (2013). "Human Health and the Neolithic Revolution: An Overview of Impacts of the Agriculture Transition on Oral Health, Epidemiology, and the Human Body." Nebraska Anthropologist, 187, 95-102.

Lim, C.I., Biswas, W., \& Samyudia, Y. (2015). "Review of Existing Sustainability Assessment Methods for Malaysian Palm Oil Production." 12 $2^{\text {th }}$ Global Conference on Sustainable Manufacturing Proceedings, 13-18.

Lipton, E. (2017) “E.P.A. Says Drift of Herbicide Damaged Crops in 25 States.” New York Times, 2 November, B1. Lynas, M. (2018). “Confession of An Anti-GMO Activist.” Review, Wall Street Journal, 23-24 June, C1-2.

Maher, K. (2018). "Researchers Race to Thwart Algae Outbreaks.” Wall Street Journal, 9 April, A3.

Miller, R. (1980). "Water use in Syria and Palestine from the Neolithic to Bronze Age." World Archaeology, 11, 3, $332-341$.

Muna, S. (2016). “The Customer is Always Right.” Borneo Post, May 22, P13.

NPR (2017). "Orangutans Moms are the Champs of Breast-Feeding." 17 May.

https://www.npr.org/sections/health-shots/2017/05/17/528776636/orangutan-moms-are-the-primatechamps-of-breast-feeding

Patel, J.K. \& Parshina-Kotaas, Y. (2017). “Miles of Algae Covering Lake Erie.” New York Times, 4 October, A11. Pleanjia, S.G. (2009). “Full Chain Energy Analysis of Biodiesel Production for Palm Oil in Thailand.” S209-214.

Plumer, B. \& Popovich, N. (2018). "Poor Americans Exposed to Unsafe Water, Study Shows.” New York Times, February 13, A10.

Pokharel, K. \& Rana, P. (2017). “The World's Next Environmental Disaster.” 21-22 October. https://www.wsj.com/articles/the-worlds-next-environmental-disaster-1508511743

Rodell, M., Velicogna, I. \& Famiglietti, J.S. (2009). “Satellite-based estimates of groundwater depletion in India.” Nature, 460, August: 999-1003.

Sayer, J., Ghazoul, J., Nelson, P. \& Boedhihartono, A.K. (2012). “Oil Palm Expansion Transforms Tropical Landscapes and Livelihoods." Global Food Security, 1, 114-119.

Schonhardt, S. (2016). “Southeast Asia Fires Tied to Deaths.” Wall Street Journal, September 20, A12.

Schuetze, C.F. \& Karasz, P. (2019). “As Swarms Collapse Worldwide, Amateur Beekeepers Keep Berlin Awash in Hives.” New York Times, August 12, A6.

Scott, J.C. (2017). Against the Grain: A Deep History of the Earliest States. New Have: Yale University Press.

Sengupta, S. \& Cai, W. (2019). "Water Crisis A Quarter of Humanity.” New York Times, August 7, A1 \& A6.

Shablovsky, S. (2017). "Hunters and foragers thrived while early agrarian societies struggled, argues an anthropologist." 1 August. http://blogs.sciencemag.org/books/2017/08/01/hunters-and-foragers-thrived-whileearly-agrarian-societies-struggled-argues-an-anthropologist/ 
Sheikh, K. (2019). “High-Tech Tools to Develop New Crops.” New York Times, June 19, A13.

Shipman, M. (2019). "Portable Tech Sniffs Out Plant Disease In The Field.” July, 29. https://news.ncsu.edu/2019/07/handheld-tech-sniffs-plant-disease/

Sinha, E., Michalak, A.M. \& Balaji, V. (2017). "Eutrophication will increase during the $21^{\text {st }}$ century as a result of precipitation changes." Science, 357, 28 July: 405-408.

Smith, M. (2019). “Tariffs, Low Grain Prices, Floodwaters and No Water at All.” New York Times, July 30, A1 \& A22.

Subramanian, M. (2019). “India's Terrifying Water Crisis.” New York Times, July 16, A23.

Tabuchi, H., Popovich, N., Migliozzi, B., \& Lehren, A.W. (2018). “Mixing Water and Poison.” New York Times, 7 February, A13.

Tan, K.T., Lee, K.T., Mohamed, A.R., \& Bhatia, S. (2009). “Palm Oil: Addressing Towards Sustainable Development.” Renewable \& Sustainable Energy Reviews, 13, 420-427.

UDP.org www.undp.org/content/dam/undp/library/Environment\%20and\%20Energy/Green\%20Commodities\%20Progr amme/Indonesia\%20Factsheet\%20pdf.pdf

Vijayakumar, S. (2012). "Simple \& cheap solution to India's grave water crisis: Waste water recycling." Economic Times, September 23.

http://articles.economictimes.indiatimes.com/2012-09-23/news/34022987 1 desalination-plant-waterresources-waste-water

Wall Street Journal (2017). “Data Science Will Transform Farming.” 16 October: R7.

World Bank (https://www.worldbank.org/en/topic/water-in-agriculture)

Yee, K.F., Tan, K.T., Abdullah, A.Z., \& Lee, K.T. (2009). “Life Cycle Assessment of Palm Biodiesel: Revealing Facts and Benefits for Sustainability." Applied Energy, 86, S189-196.

Zimmer, C. (2019). Ancient Ancestors Liked Mountains Views, Too.” New York Times, August 13, D6. 